\title{
Sediment rafting: a novel mechanism for the small- scale dispersal of intertidal estuarine meiofauna
}

\author{
Geoffrey R. F. Hicks \\ National Museum of New Zealand, PO Box 467, Wellington, New Zealand
}

\begin{abstract}
Epontic diatoms from intertidal sandy sediments produce considerable quantities of extracellular mucopolysaccharides that are used for locomotion, adhesion to sediment particles and as antidesiccants. These mucoid exopolymers dry out during low tide and cement sandgrains together thus stabilizing the surficial deposit. Under benign microclimatic conditions in Pauatahanui Inlet, New Zealand, these mucoid films with bound surface sediments peel off the substratum and float onto the surface of incoming tidal waters. Large numbers of meiofaunal organisms are carried aboard these films which can subsequently be rafted considerable distances (10's of metres) at the whim of tidal currents and winds. Locally abundant epibenthic copepods are most prone to be passively conveyed in this way: and numbers on rafts are dependent on both microspatial and temporal factors that control population density at the site. Tiny naupliar stages of the harpacticoid Parastenhelia megarostrum dominate the rafted population, due to their intimate clinging association with surficial particles. Survivorship is high in individuals that have undergone rafting; rafts thus function as effective agents of dispersal for intertidal epibenthic meiofauna. Along with active migration by crawling and passive water column transport, this is the third significant pathway of small-scale within-locality dispersal for meiofauna to be revealed and investigated. It must be considered as a contributing mechanism of recruitment for meiofaunal organisms known to rapidly recolonıze disturbed or denuded habitat.
\end{abstract}

\section{INTRODUCTION}

Meiofauna are small mobile benthic metazoans Despite their lack of freely dispersing planktonic larvae, one might expect that because of their small size and mass and their frequent association with floating objects (e.g. algae), they would be ideal propagules for passive dispersal. The result would be distribution patterns that would be widespread for most and cosmopolitan for many (Gislén 1940, Chislenko 1974, see also Hulings \& Gray 1971, Sterrer 1973). While this is an oversimplification, the fact remains that a great number of meiofaunal species are not widespread but are extremely localized in their biogeographic occurrence.

In any discussion of biogeography, the question of scale in both time and distance must be addressed before meaningful conclusions can be reached about aspects of a species' distribution or mechanisms whereby the species is dispersed. Such discussions may subdivide dispersal mechanisms into large- or small-scale events which may be operative over long- or short-time scales. Agents of long distance dispersal are those invoked to explain faunal affinities between landmasses separated by present day oceanic basins. Operating on a medium or ecologically relevant time frame are dispersal mechanisms associated with transoceanic or epiplanktonic drift and include rafting on ice, driftwood, seaweed or other flotsam, aerially through avian vectors or via anthropogenic sources such as shipping (Yeatman 1962, Wiborg 1964, Gerlach 1977. Carlton 1985). Operating on a longer or evolutionary time frame are dispersal routines relying on geologically historical or vicariant events such as the fragmentation and dispersal of continental margins carrying with them entire biotopes (Sewell 1956, Sterrer 1973, Hicks 1977, Wells 1986). Not until very recently have controlled experimental data been forthcoming that test the efficacy of any of these 'megadispersalist' hypotheses (Kingsford \& Choat 1985, Edgar 1987).

Contrasting with these large-scale or global mechanisms of dispersal are those that operate on very small, often spatially discrete scales, but which are neverthe- 


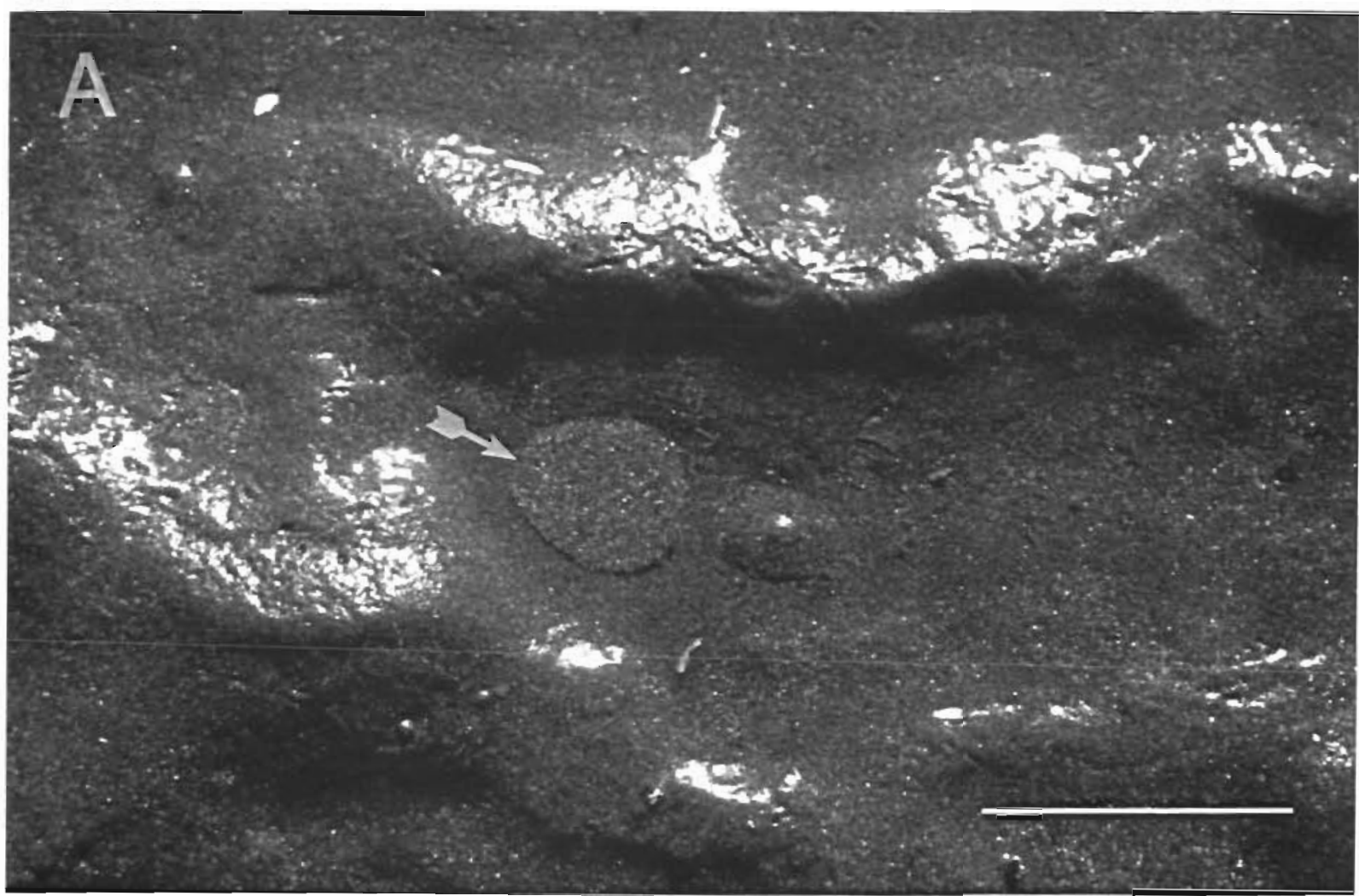

Fig. 1. Floating sediment films. (A) Small raft (arrowed) having just peeled off trough of intertidal sand ripple, scale bar $=60 \mathrm{~mm}$. Opposite: (B) Larger coalesced raft floating over $70 \mathrm{~mm}$ of water, note shadow cast on underlying substratum (arrow), scale bar $=$ $300 \mathrm{~mm}$. (C) Larger coalesced raft over $40 \mathrm{~mm}$ water, note shadow cast on underlying substratum (arrow), scale bar $=100 \mathrm{~mm}$

less of great importance to the functional integrity of populations, particularly in sheltered environments. Such 'microdispersalist' mechanisms offer pathways for meiobenthic organisms to be relocated at time scales in the order of minutes-hours and over distances up to tens of metres. Apart from over or through sediment locomotion, another major pathway of meiofaunal dispersal in estuarine habitats has received extensive investigation and relies on water column entry by individuals. Erosion of small organisms can occur when the friction velocity of tidal currents exceeds a threshold level (Fleeger et al. 1984, Palmer \& Gust 1985, Palmer 1986), animals thus becoming suspended in the water column as passive particles. Moreover, Palmer (1984), Palmer \& Molloy (1986) and Fegley (1987) have demonstrated that certain meiofaunal taxa behaviourally adjust their vertical distribution in sediments, thus increasing or decreasing their susceptibility to transport. Compared with this passive mode of entry into the water column, is active swimming which has been shown to involve a high proportion $(<60 \%$ ) of resident populations (Walters 1987). Active swimming occurs at times with and without flow and at times that vary according to day or night and to the state of the tide (Hicks 1986, Waiters \& Bell 1986, Bell et al. 1988)
Irrespective of the mode or reasons (see Bell et al. 1988) for entry into the water column, meiofaunal animals finding themselves in this circumstance, and separated from the substratum, then become propagules for dispersal at the whim of tide, wind or geostrophically driven currents

Despite the advances made in documenting the susceptibility, occurrence and frequency of meiofaunal animals to be found participating in these particular dispersal events, conclusive data on the performance of such events are lacking. In order to actively demonstrate that species are dispersed sensu stricto by one means or another, it becomes necessary to show that individuals of an existing population are moved from a site they typically inhabit, to arrive at a new site and, moreover, that the same individuals are capable of survival and persistence at the new location (Highsmith 1985). In this paper I present evidence of a new method of small-scale meiofaunal dispersal. It is a modified but previously unreported component of the rafting hypothesis (Gerlach 1977), involving floating sediment films (henceforth termed 'rafts'), that convey meiofauna considerable distances within enclosed water bodies. Quantification of this dispersal mechanism is provided by addressing questions relating to the 

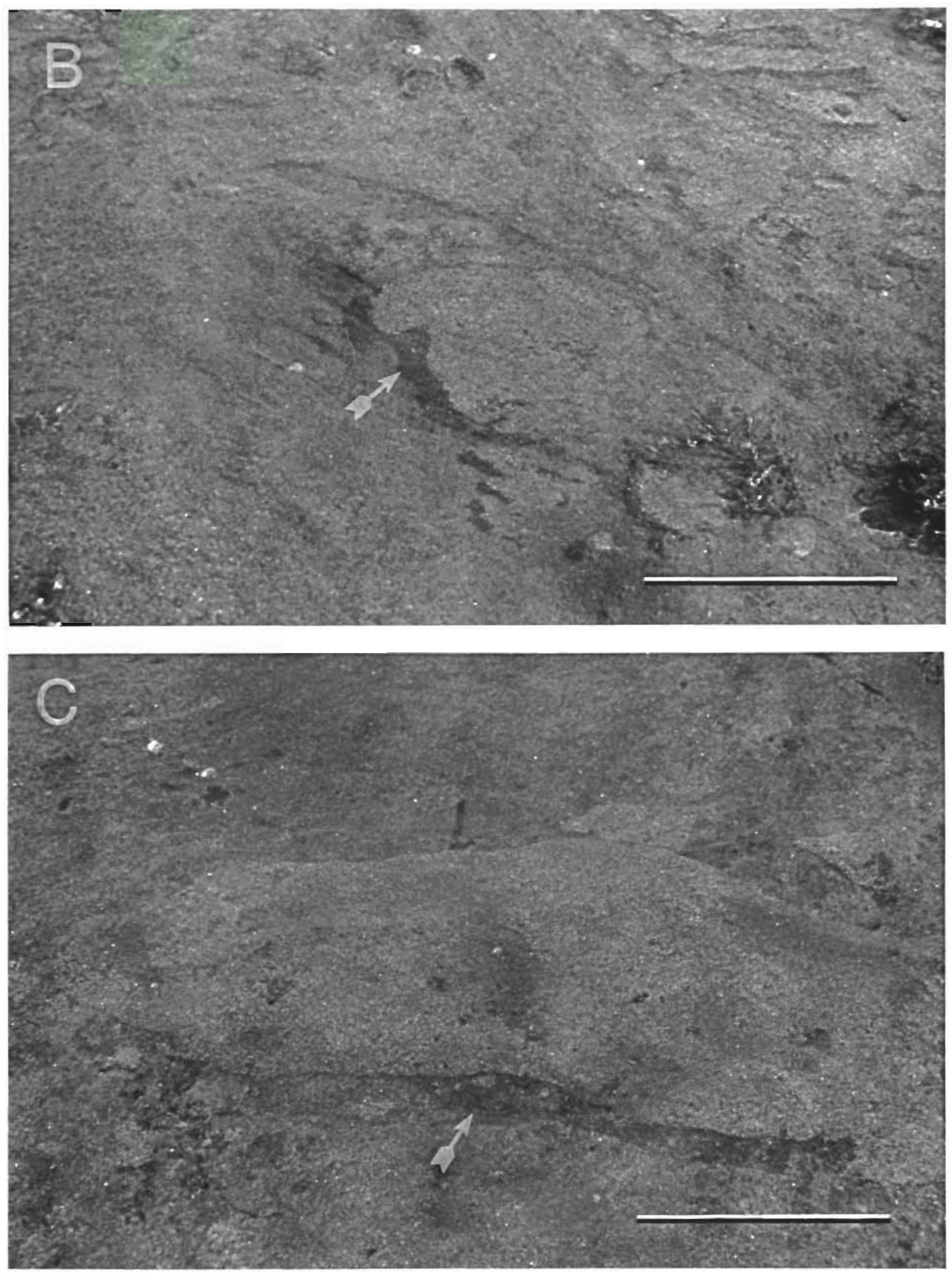
composition and abundance of meiofauna on and off rafts, distances travelled, the fate of the rafted population and implications this mode of dispersal has for rapid recolonization and reassortment of populations on new, disturbed or denuded habitat.

\section{METHODS AND MATERIALS}

Study site. All observations and collections reported herein were made on the edges of a shallow tidal drainage channel, flanking the western side of Mana Bank in Pauatahanui Inlet, Wellington, New Zealand $\left(41^{\circ} 06^{\prime} \mathrm{S}, 174^{\circ} 54^{\prime} \mathrm{E}\right)$. Mana Bank is an emergent intertidal sandbank, characterized by persistent yet mobile surface ripples and fringing beds of the eelgrass Zostera capricorni Aschers. The sediment is a well-sorted fine sand with about $2 \%$ silt-clay. Semidiurnal tides are experienced at this site with a mean spring range of $1.25 \mathrm{~m}$. Local wind and atmospheric conditions greatly influence sea level, tidal range and water flows over the sandbanks, with accompanying changes in the state of the sea surface (see Hicks 1984, 1986 for further details of the site).

Description and occurrence of sediment rafts. Under benign local weather conditions, as an incoming tidal front moves over exposed sediment, discrete plaques of dry surface deposit passively peel off and, supported by high surface tension, float onto the surface of the encroaching wedge of water. These buoyant films of only a few sandgrains thickness drift forward parallel to current flow, but may oscillate in direction depending on internal water motion or the amount and direction of breeze. The origin of these films is spatially irregular, but observations suggest that depressions and irregularities in the exposed substratum such as sand ripple troughs (Fig. 1a) and old fish feeding pits give rise to proportionately more rafts than flat gently sloping faces. Equally, the size of rafts is greatly variable (measured in situ as maximum surface diameter); whilst drifting, small rafts ( $<30 \mathrm{~mm}$ diam.) frequently coalesce to form larger patches ( $>200 \mathrm{~mm}$ diam.) of moving sediment (Fig. 1b, c). Rafts can be encountered at the site throughout the year during conditions of calm surface waters. Their breakdown or disintegration results naturally after a period of water surface drift. Disturbed water conditions lead to rapid breakdown of rafts and a rough water surface caused largely by local wind effects prevents the establishment of rafts. The appearance of rafts is therefore intimately linked with local climatic conditions.

Sampling. Individual rafts of a range of establishment sizes (i.e. those observed lifting off basement sediments), together with larger coalesced patches or 'streamers', were sampled in the following way.
Shallow sieves of $63 \mu \mathrm{m}$ mesh constructed from $10.4 \mathrm{~cm}$ diameter PVC pipe were gently submerged at an angle oblique to the track of a drifting raft. Care was taken not to sample the water column preceding the raft, so the lip of the sieve closest to the approaching raft was maintained slightly above the water surface. Just prior to raft contact with the sieve lip, the latter was quickly tilted below the water surface acting as a suction device which drew this floating material onto the sieve. Thirty such samples were randomly taken across rafts of differing dimension. Once isolated on the sieve the entire sample was washed live with filtered habitat water into collecting jars and returned to the laboratory. The sample was sieved to remove the bulk of the sediment and was examined under a Wild M5A binocular microscope before the addition of $70 \%$ alcohol and Rose Bengal stain. Samples were then precisely sieved and decanted to remove all sediment and fauna; the retained sediment, which is in the size range 125 to $250 \mu \mathrm{m}$, was then committed to a $10 \mathrm{ml}$ measuring cylinder to determine settled volumes. Abundance values are expressed as number of individuals per total raft sampled. Raft size is equivalent to the settled volumes of sediment. As a check on composition of raft fauna versus that from surrounding sediments, cores were taken on 19 October 1987 immediately adjacent to raft origins with a $23 \mathrm{~mm}$ diameter brass corer, pushed into the substratum to the RPD. Samples were preserved, stained and laboratorytreated as above.

Distance travelled by rafts was calculated in the following way. On 18 September, 27 October, 2 November and 12 December 1987, during calm conditions with either no wind or a light SW and directionally consistent breeze, individual rafts travelling in a roughly linear fashion on the rising tidal front were identified. At the point of identification a stake was implanted on the channel bank. The raft was then tracked until it naturally disintegrated. If a small discrete raft coalesced into a larger patch, the total passage was followed until disintegration. At the moment of break up a second stake was driven into the substratum; distances traversed are therefore the linear dimension between both stakes

Meiofaunal 'passengers' aboard disintegrating rafts were assessed as follows. Discrete rafts were identified and tracked for $12 \mathrm{~m}$ over a water depth of about $10 \mathrm{~cm}$. Upon arrival at this predetermined 'new' destination, rafts were physically disrupted by agitation of the adjacent water surface. This caused rafts to lose their integrity and break down and the constituents to sink to the bottom. At a depth of 5 to $8 \mathrm{~cm}$ below the surface were held 2 contiguous sieves (as above). These were maintained parallel to the trajectory of the moving raft. As the raft broke down, the sieves were manipulated to catch 
the falling contents. The first sieve (A) was held immediately below the raft and collected most of the sinking sandgrains and associates. The second sieve (B) located behind the main body of sediment fall collected contents that it was suspected descended obliquely to the bottom. In this way it was hypothesized that a distinction could be made between organisms intimately associated with the sediment grains and therefore more likely to be collected in Sieve A, and those more independent of the sediment, collected in Sieve B. The catch from this experiment was treated as above.

\section{RESULTS}

\section{Nature of raft cohesion}

In the field, the degree of cohesion exhibited between the constituent sandgrains forming rafts is striking (Fig. 1). In the laboratory it was noticed that large numbers of benthic diatoms were recovered from samples during the sieving procedures for raft meiofauna. Amongst the contained diatoms, the following were identified with the aid of Crosby \& Ferguson Wood (1959): Tropidoneis lepidoptera (dominant). Pleurosigma balticum, Nitzchia closterium, Synedra gaillonii, Pleurosigma sp. aff. formosum, Achnanthes $\mathrm{sp}$. While most of these cells appeared free in the filtrate, a sufficient number could still be observed attached and clustered on sandgrains. Diatoms are known to utilize mucopolysaccharide exopolymers to attach to both terrigenous and biogenic surfaces (e.g. Daniel et al. 1987). To test if mucoid substances were responsible for 'gluing' sandgrains together into discrete patches constituting rafts, aqueous Toluidine blue 0 stain was pipetted onto raft material that had been gently floated onto microscope slides in the field and dried in air. Toluidine blue (with benzoate buffer, $\mathrm{pH}$ 4.4 ) reacts to a purple-pink colour in the presence of sulfated and carboxylated polysaccharides (McCully et

Table 1. Total numbers of invertebrate taxa collected from sediment rafts, Pauatahanui Inlet, June to December 1987 . -: not represented. $n=30$

\begin{tabular}{|c|c|c|c|c|c|c|c|}
\hline \multirow{2}{*}{$\begin{array}{l}\text { Sediment vol. } \\
\text { (ml) }\end{array}$} & \multicolumn{7}{|c|}{ Taxon (no. of individuals) } \\
\hline & Harpacticoida & Nematoda & Ostracoda & Cyclopoida & Amphipoda & Polychaeta & Total \\
\hline 0.1 & 7 & - & - & - & - & - & 7 \\
\hline 0.6 & 177 & 8 & 5 & - & - & - & 190 \\
\hline 0.8 & 51 & 13 & 4 & 1 & - & - & 69 \\
\hline 0.9 & 13 & 3 & - & - & - & - & 16 \\
\hline 1.2 & 148 & 12 & 1 & - & 2 & - & 163 \\
\hline 1.3 & 217 & 26 & 4 & - & 1 & - & 248 \\
\hline 1.3 & 41 & 31 & - & - & -- & - & 72 \\
\hline 1.4 & 47 & 7 & 1 & - & 2 & - & 57 \\
\hline 1.5 & 92 & 9 & 2 & - & - & 1 & 104 \\
\hline 1.6 & 96 & 15 & 5 & - & 1 & - & 116 \\
\hline 1.6 & 80 & 2 & - & - & 4 & - & 86 \\
\hline 1.7 & 22 & 2 & - & - & - & - & 24 \\
\hline 1.9 & 102 & 3 & - & 1 & 4 & - & 110 \\
\hline 1.9 & 37 & 4 & - & - & - & 1 & 42 \\
\hline 2.0 & 197 & 21 & - & 1 & - & - & 219 \\
\hline 2.1 & 90 & 8 & 2 & 1 & 1 & - & 102 \\
\hline 2.2 & 77 & 2 & - & - & 10 & - & 89 \\
\hline 2.4 & 319 & 6 & - & - & 10 & - & 335 \\
\hline 2.6 & 11 & 6 & - & - & 1 & - & 18 \\
\hline 2.8 & 45 & 13 & 2 & - & 2 & - & 62 \\
\hline 2.8 & 692 & 7 & - & - & 24 & - & 723 \\
\hline 3.3 & 469 & 11 & - & - & 18 & - & 498 \\
\hline 3.3 & 503 & 18 & 1 & - & 11 & - & 533 \\
\hline 3.3 & 131 & 7 & - & - & 12 & - & 150 \\
\hline 3.4 & 533 & 21 & 1 & - & 5 & - & 560 \\
\hline 3.5 & 264 & 18 & 3 & 1 & 2 & - & 288 \\
\hline 3.8 & 389 & 13 & 4 & 1 & 3 & 2 & 412 \\
\hline 4.2 & 205 & 11 & - & - & 13 & - & 229 \\
\hline $\begin{array}{l}4.2 \\
4.2\end{array}$ & 26 & 34 & 4 & - & - & - & 64 \\
\hline 5.2 & 819 & 20 & 10 & - & 1 & - & 850 \\
\hline Total & 5900 & 351 & 49 & 6 & 127 & 4 & 6436 \\
\hline$\overline{\mathrm{x}}$ & 196.7 & 11.7 & 1.6 & 0.2 & 4.2 & 0.1 & 214.5 \\
\hline$\hat{\mathrm{SD}}$ & 213.9 & 8.7 & 2.3 & 0.4 & 6.1 & 0.4 & 220.4 \\
\hline
\end{tabular}


al. 1980). Eight such rafts were stained in this way and in each case purple material was present on and between grains, indicating the presence of 'microbial' mucopolysaccharide. The term 'microbial' is used here because no distinction could be made between exopolymers from diatoms or those known also to be exuded by bacteria (e.g. Fletcher \& Floodgate 1973, Costerton et al. 1978). These cellular exudates are considered responsible for maintaining the integrity of rafts by acting as bridging agents binding sandgrains together (Grant et al. 1986). Mucus of meiofaunal origin may also contribute to this, but its relative importance over 'microbial' productions remains unknown and untested.

\section{Composition of the rafted fauna}

Floating sediment films carry large numbers of invertebrate taxa, with by far the predominant group being meiofauna (Table 1). Harpacticoid copepods are the single most abundant taxon with individuals occurring on all rafts sampled. Cumulatively they contribute $91.7 \%$ of the rafted fauna, with nematodes $(5.4 \%)$ second in abundance. All other groups, including the typically macrofaunal Amphipoda (one species, Para- calliope novizealandiae) and Polychaeta, made up the remainder $(2.9 \%)$.

Of the nearly 6000 harpacticoids enumerated, nearly all $(95.4 \%$ ) belong to Parastenhelia megarostrum, an epibenthic species occurring in very high numbers at this site (Hicks 1984, 1985). Another 20 species were represented but always in low numbers (Table 2). Most species appearing on rafts can be categorized as either epibenthic or itinerant in their microhabitat specialization. Rafts from the smallest $(0.1 \mathrm{ml}$ sediment $)$ to the largest (5.2 $\mathrm{ml}$ sediment) sampled consistently revealed specimens of $P$. megarostrum, with at least one individual of either Ectinosoma melaniceps, Halectinosoma hydrofuge, Tisbe spp. (furcata and holothuriae) or Quinquelaophonte candelabrum occurring at frequencies of greater than $35 \%$ (Table 2).

Of those individuals of Parastenhelia megarostrum recovered from rafts, the overwhelming majority (94.3\%) are juveniles (nauplii and copepodites), and of these the larval stages dominate $(85.3 \%$; Table 3$)$. The abundance of not only nauplii, but of the whole population varies greatly between samples, evidenced by the variance being much greater than the mean in each case. Samples were taken over periods including high (e.g. late June, late October) and low (early December) ambient population density at this locality. To test if the

Table 2. Relative abundance and frequency of occurrence of harpacticoid copepods collected from sediment rafts, Pauatahanui Inlet, June to December 1987 Arbitrary categories ranked as primarily epibenthic sediment-dwellers, some of which may be shallow burrowers (Es); itinerants, commonly found on both sediments and vegetation (It); planktonic (Pl); phytal (Ph); interstitial (In)

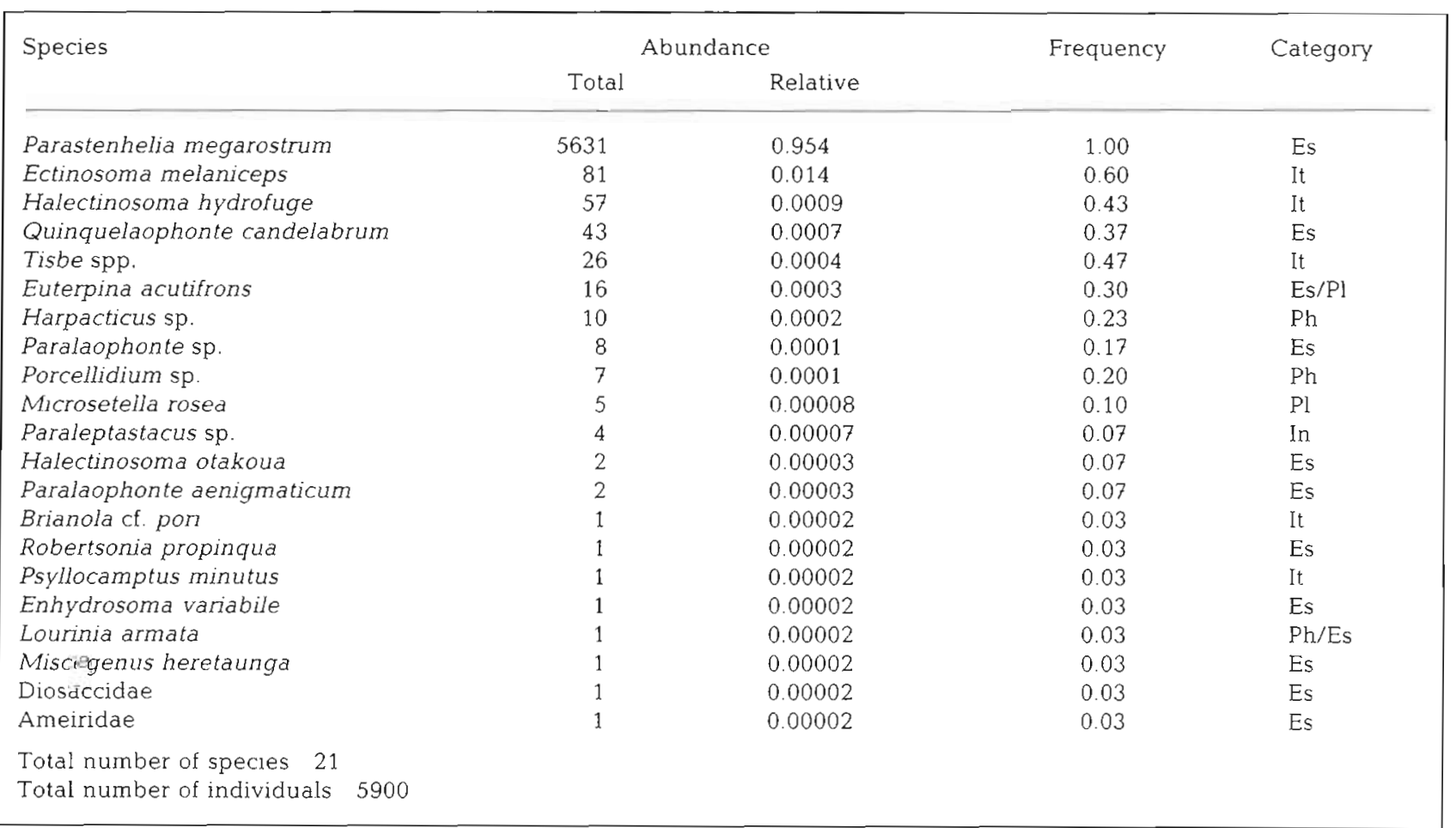


life history stages occupying rafts differed from adjacent underlying substratum, 6 cores were taken in the vicinity of forming rafts on 19 October 1987, at a time of naupliar recruitment to the population. Care was taken to identify coring stations that had not recently contributed to rafts. Nauplii are disproportionately more abundant on rafts, than on the adjacent substratum (Table 4), while copepodites and adults are less so ( $G$ test, $p<0.05$ in 3 paired comparisons of percentages). Larger and therefore older individuals in the sediment population are less likely than the larval phase to be found being transported on rafts.

To identify if raft size influenced the abundance of those Parastenhelia megarostrum being conveyed, number of individuals was correlated with volume (ml) of sediment raft material. There is a significant relation between these 2 variables ( $r=0.536, p<0.005$ ), but the scatter in the data is pronounced (Fig. 2). It would be fair to say that the association between copepod abundance and raft size is a loose one, highly dependent upon factors such as time of year and the level of contagion in the underlying substratum population at the time of sampling.

\section{Distance travelled by rafts}

A total of 21 individual rafts identified at their point of origin were tracked until disintegration and their trajectory measured. Observations were made over 4 dates (see 'Methods and Materials'), at the rising of both neap and spring tides and during non-equivalent weather conditions. Local wind and wave conditions are critical not only for the formation of rafts, but also for their cohesion and maintenance during conveyance. Distances covered are shown in Fig. 3 and show great variability, with a maximum recorded of $62.8 \mathrm{~m}$ on 2 November. This occasion seems to have been optimal for raft durability and transport with a very light and directionally consistent (i.e. no cross current) southerly breeze, combined with a strong inflowing spring tide providing good unidirectional movement and little in the way of raft coalescence. Coalescence of rafts occurs most commonly during cross wind or eddying conditions which run perpendicular or counter to tidal current flow. Of those observations made, a mean distance of $17.6 \mathrm{~m}( \pm 16.1)$ was traversed by identifiable rafts. Using this average figure and assuming it holds on a daily basis, rafts would take about $98 \mathrm{~d}$ to cover the maximum $3.5 \mathrm{~km}$ length of the inlet, or ca 323 $\mathrm{d}(\approx 11 \mathrm{mo})$ to complete a circumnavigation of the inlet's $4.5 \mathrm{~km}^{2}$ area.

\section{Fate of rafted population}

Comparison of individuals collected in samples immediately below disrupted intact rafts and retaining

Table 3. Parastenhelia megarostrum. Life history stage composition of the rafted population, June to December 1987

\begin{tabular}{|lccccc|}
\hline & Nauplii & Copepodites & Adult males & Adult females & Ovigerous females \\
\hline Total number & 4806 & 508 & 134 & 117 & \\
$\bar{X}$ & 160.2 & 16.9 & 4.5 & 5.9 & 6.3 \\
SD & 180.2 & 26.9 & 5.3 & 28.1 & 3.0 \\
$S^{2}$ & 32508.1 & 723.6 & 2.4 & 2.1 & 9.0 \\
$\%$ of total & 85.3 & 9.0 & & 1.2 \\
\hline
\end{tabular}

Table 4. Parastenhelia megarostrum. Life history stages on sediment rafts compared with those from sediment cores taken in the vicinity, 19 October 1987. Size of rafts varies from 2.8 to $4.2 \mathrm{ml}$ of sediment by volume; the corer samples $4.15 \mathrm{~cm}^{2}$ of sediment, numerical values are therefore not directly comparable

\begin{tabular}{|c|c|c|c|c|c|c|c|c|c|c|c|}
\hline \multicolumn{6}{|c|}{ Sediment rafts } & \multicolumn{6}{|c|}{ Sediment cores } \\
\hline $\begin{array}{c}\text { No. } \\
\text { nauplij }\end{array}$ & $\%$ & $\begin{array}{l}\text { No. } \\
\text { copepo- } \\
\text { dites }\end{array}$ & $\%$ & $\begin{array}{l}\text { No. } \\
\text { adults }\end{array}$ & $\%$ & $\begin{array}{c}\text { No. } \\
\text { nauplii }\end{array}$ & $\%$ & $\begin{array}{l}\text { No. } \\
\text { copepo- } \\
\text { dites }\end{array}$ & $\%$ & $\begin{array}{l}\text { No. } \\
\text { adults }\end{array}$ & $\%$ \\
\hline 466 & 88.9 & 29 & 5.5 & 29 & 5.5 & 1441 & 82.3 & 161 & 9.2 & 148 & 8.5 \\
\hline 389 & 87.6 & 37 & 8.3 & 18 & 4.1 & 1297 & 79.8 & 192 & 11.8 & 137 & 8.4 \\
\hline 630 & 92.5 & 44 & 6.5 & 7 & 1.0 & 1482 & 81.6 & 209 & 11.5 & 125 & 6.9 \\
\hline 272 & 88.3 & 24 & 7.8 & 12 & 3.9 & 947 & 73.5 & 148 & 11.5 & 193 & 15.0 \\
\hline 175 & 94.1 & 7 & 3.8 & 4 & 2.2 & 1833 & 82.0 & 241 & 10.8 & 162 & 7.2 \\
\hline 425 & 86.7 & 40 & 8.2 & 25 & 5.1 & 1966 & 81.5 & 226 & 9.4 & 219 & 9.1 \\
\hline $\bar{x} \%$ & 89.7 & & 6.7 & & 3.6 & & 80.1 & & 10.7 & & 9.2 \\
\hline
\end{tabular}




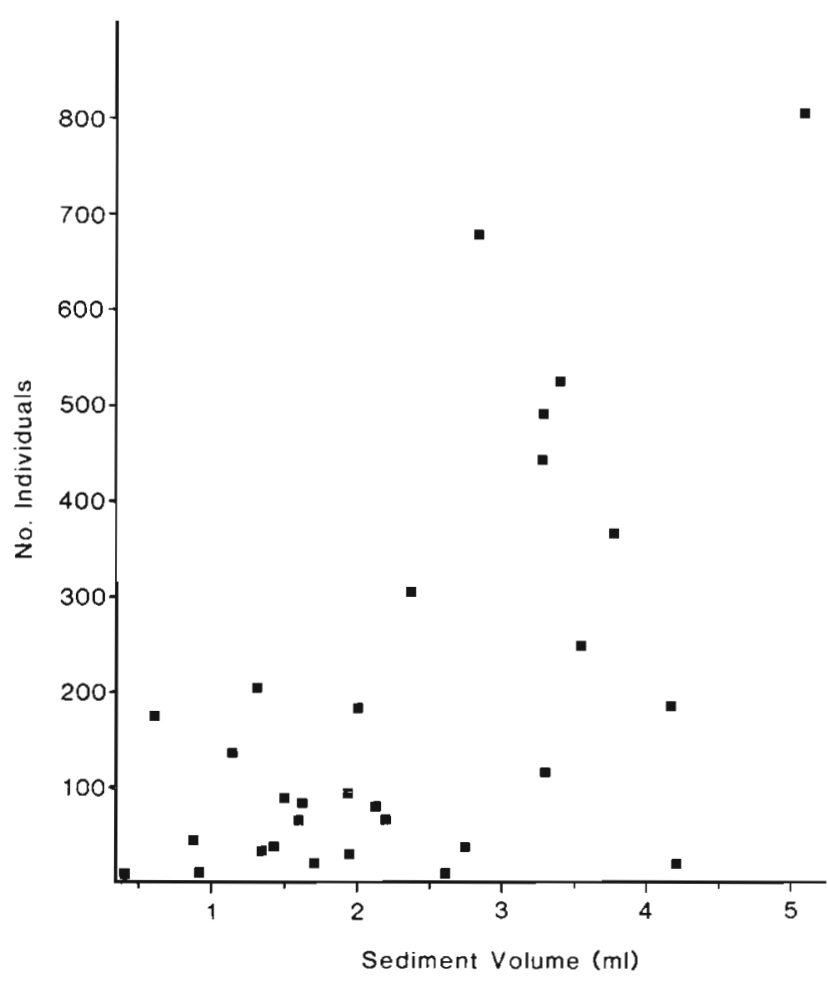

Fig. 2. Darastenhelia megarostrum. Relation between total number of individuals and raft size, determined as settled volume $(\mathrm{ml})$ of raft sediment, $(n=30)$

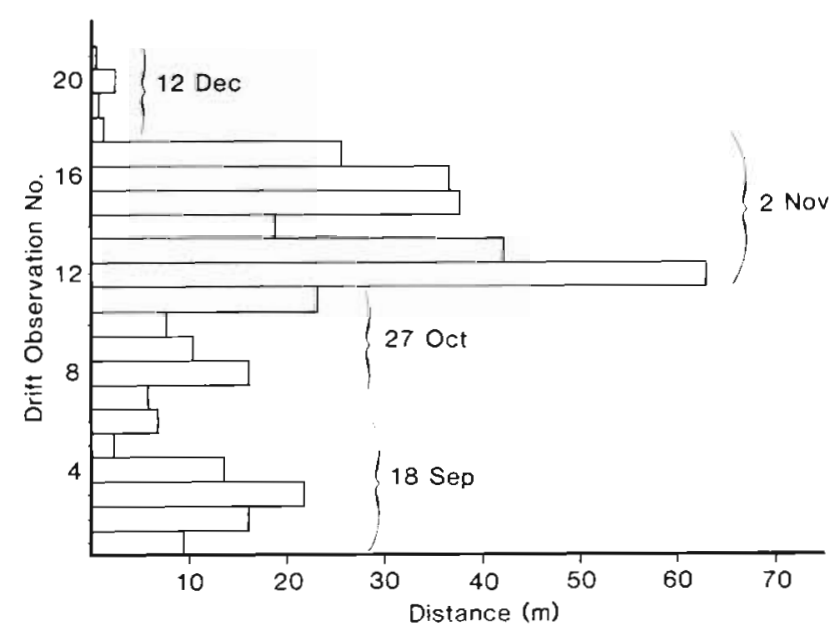

Fig. 3. Distance traversed by floating sediment rafts on 4 dates in 1987 Each measurement is the linear distance from origin to natural disintegration. $18 \mathrm{Sep}, n=6 ; 27$ Oct, $n=5 ; 2$ Nov,

$$
n=6 ; 12 \text { Dec, } n=4
$$

the bulk of the raft material (Sieve A), with those from Sieve B located behind but contiguous with the former, reveals an apparent difference in the way various life history components of the Parastenhelia megarostrum population return to the substratum. A t-test shows a significantly $(p<0.001)$ higher number of nauplii caught in Sieve A, compared with Sieve B (Table 5). In contrast, while the actual numbers are too small for statistical treatment, a higher abundance of adults (lumped males and females) were found in Sieve B than Sieve A, while no significant difference could be ascertained for copepodites ( $t$-test). These results suggest a varying degree of fidelity to the material constituting the raft matrix.

All samples were returned live to the laboratory for observation prior to preservation. A high level of survival of all components of the population was noticed, even after some $2 \mathrm{~h}$ of disturbance during transportation and sieving. Moreover, one sample left at room temperature in the laboratory overnight (a total of $18 \mathrm{~h}$ after field sampling), revealed a greater than $75 \%$ survivorship for nauplii alone. These observations would suggest that raft-borne individuals would in most cases be alive and well when redeposited upon habitat sediment at the termination of normal rafting activities.

\section{DISCUSSION}

The present report illustrates the great potential for small-scale intralocality dispersal of epibenthic meiofauna on floating sediment films. The frequency at which sediment rafts occur and the distances over which they convey their meiofaunal passengers is greatly variable and at the dictate of microclimatic conditions at the site. The highly ephemeral nature of floating sediment films is equally a function of the spatial concentrations of epontic diatoms which are ultimately responsible for the cementing of sandgrains leading thus to the formation of floating rafts. Diatoms that migrate interstitially (Harper 1969, Joint et al. 1982) are known to congregate at the sediment surface during low tide where they maximize their photosynthetic potential (Taylor 1964, and see inter alia, Palmer \& Round 1967). Mucopolysaccharides excreted as products of cell respiration are used by diatoms not only as adhesives for attachment to particles, but also as antidesiccants during exposure. Both are clearly important adaptations for intertidal diatoms (Harper \& Harper 1967, Daniel et al. 1987). Furthermore, mucus is utilized for locomotion purposes in these organisms during rhythmic light-tide coupled excursions through the sediment matrix (Harper 1969). The net effect of the considerable quantities of mucopolysaccharide laid down on exposed sediment surfaces is to 'glue' particles together and stabilize surficial deposits (Probert 1984, Grant et al 1986), which provides the high surface layer integrity necessary to peel or float off onto the interface of incoming tidal waters.

The harpacticoid copepod Parastenhelia megarostrum is the commonest meiofaunal animal to be found 
Table 5. Parastenhelia megarostrum. Number and composition of specimens collected immediately below disrupted raft (A), and in a contiguous sample (B) located behind the main body of sediment fall, 2 November 1987 (see text for details)

\begin{tabular}{|c|c|c|c|c|c|c|}
\hline Sample no. & Nauplii & $\begin{array}{l}\text { Number in A } \\
\text { Copepodites }\end{array}$ & Adults & Nauplii & $\begin{array}{l}\text { Number in B } \\
\text { Copepodites }\end{array}$ & Adults \\
\hline 1 & 45 & 1 & 0 & 2 & 0 & 1 \\
\hline 2 & 87 & 4 & 0 & 4 & 12 & 1 \\
\hline 3 & 58 & 2 & 1 & 5 & 4 & 4 \\
\hline 4 & 32 & 3 & 0 & 9 & 3 & 5 \\
\hline 5 & 68 & 5 & 0 & 12 & 9 & 2 \\
\hline 6 & 118 & 6 & 1 & 0 & 19 & 0 \\
\hline 7 & 160 & 5 & 0 & 7 & 2 & 1 \\
\hline Total & 568 & 26 & 2 & 39 & 49 & 14 \\
\hline$\overline{\mathrm{x}}$ & 81.1 & 3.7 & 0.3 & 5.6 & 7.0 & 2.0 \\
\hline $\mathrm{SD}$ & 44.8 & 1.8 & 0.5 & 4.1 & 6.7 & 1.8 \\
\hline
\end{tabular}

on rafts at this site and is a reflection of the microhabitat occupied by this species. It is the most abundant truly epibenthic copepod at this site. Previous in situ stereomicroscope observations have revealed that the larger specimens (copepodites and adults) spend most of their time either on the very surface of the substratum or, more particularly, burrowed to a depth of about $1 \mathrm{~mm}$. They can be seen forcing their way, mole-like, through the surficial deposit displacing sediment grains above and beside them. Nauplii are most frequently encountered crawling and clinging to sand particles at the surface and in the top visible interstices. Unlike other harpacticoids at this site, e.g. the deeperdwelling interstitial Paraleptastacus sp. and less frequently collected epibenthic burrowing species, susceptibility of members of the $P$. megarostrum population to the passive lifting process by rafts is closely linked with these particular characteristics of its habitat occupancy. The relatively small number of interstitial copepods and nematodes on rafts compared to ambient densities is probably because they live deeper in the sediment and, in the case of nematodes, are known to burrow during ebbing and flooding tides (Boaden \& Platt 1971, Fegley 1987).

Grant et al. (1986) have shown that diatom-generated mucus films, the ingredients of rafts, are patchy on a scale of centimetres and that these patches correspond largely with sediment ripple troughs. In the present investigation, rafts were frequently seen originating in troughs and microtopographic depressions in the sediment surface (Fig. 1a). Parastenhelia megarostrum also reaches its highest population densities in ripple troughs (Hicks 1984). Microbial-meiofaunal correlations of this sort are believed to be linked to trophic considerations (Findlay 1981, Montagna et al, 1983), since bacteria and diatoms, with and without detritus, and perhaps also microbial exopolymers, constitute the primary in situ diet of meiofauna (Hicks \& Coull 1983,
Heip et al. 1985). Thus the association of very high densities of $P$. megarostrum with areas of high diatom abundance might be expected, but nevertheless ensures great potential for conveyance on forming rafts. Of course the number of copepods ending up on rafts is a function of not only these microspatial characteristics, but also variations in total population density over a given year. Abundance variations in both space and time are extreme in P. megarostrum (Hicks 1984) and both would expectedly contribute to the scatter in Fig. 2. Sampling of rafts occupied periods of both low (early December) and high (late September) ambient densities and no doubt rafts were derived from patches exhibiting varying degrees of population aggregation which is known to occur on a scale of about 2 to $12 \mathrm{~cm}$ diameter (Hicks 1984).

Dispersal between sites within a locality may often vary with life history stage or sex. For example, mature ovigerous females are the commonest dispersing stage in Tisbe cucumariae (Lopez 1982), while nauplii are the primary dispersers and colonizers in Scutellidium lamellipes (Gunnill 1982), at least over short ( $<3 \mathrm{~m}$ ) distances, and young copepodites of Zausodes arenicolus and Paradactylopodia brevicornis respond first when recolonizing sediments (Kern \& Bell 1984). The disproportionate abundance of nauplii on rafts compared with the adjacent substratum (Table 4) implies a more intimate association of the tiny larval stages with sediment grains leading to their passive removal from the surface of the seabed. Many of the larger and more mobile copepodites and adults presumably abandon the sediment film as it peels away from the underlying sediment, leading thus to a lower proportional contribution to the rafted population. Similarly as rafts disintegrate, more nauplii are collected along with the sinking sediment than are those older stages ultimately remaining on rafts (Table 5). Adults and copepodites are more likely to make their way back to the bottom 
obliquely through the water column, probably under their own motive power, but independent of the sinking raft material. Results from both of these sets of observations serve to support a previous suggestion (Hicks 1984), that the nauplii of Parastenhelia megarostrum cling to and so exhibit a higher level of fidelity for sediment grains than the older life history stages. The propensity for survival of these propagules on returning to the bottom at a 'new' destination, would seem to be very high. Laboratory observations of individuals collected from rafts and submitted to quite vigorous transportation and sieving treatments revealed that despite these disruptions a substantial proportion remained alive and active for some hours after collection. Clearly it is reasonable to assume that individuals in the field that drop back to the bottom from disintegrating rafts are viable and would proceed to contribute to population and community processes at the new site. I suggest that this is definitive evidence of the efficacy of sediment films as an agent of meiofaunal dispersal operational over short to medium withinlocality distances.

The portability of selected components of meiofaunal populations as illustrated here raises the important question of the influence these small-scale processes have on population and community functioning. In particular, identification of the means of organism dispersal allows the identification of pathways of recruitment that assist in colonization of new or previously uninhabited areas, or recolonization of habitat patches disturbed or denuded by biological or physical events. In finding that meiofaunal abundances on an artificially disturbed intertidal mudbank rapidly returned to ambient levels within the space of one tidal cycle $(12$ h), Sherman \& Coull (1980) suggested that incoming recruits to the disturbed patch did so by either active mobility over the sediment surface, or passively via tidal transport in the water column. These 2 pathways have repeatedly been invoked as those of importance in the rapid reestablishment of meiofaunal densities in habitats either naturally disturbed or artificially manipulated (Bell \& Sherman 1980, Thistle 1980, Hockin \& Ollason 1981, Reidenauer \& Thistle 1981, Bell \& Coen 1982, Van Blaricom 1982. Alongi et al. 1983, Chandler \& Fleeger 1983, Sherman et al. 1983, Ambrose 1986). Results from reports by Palmer (1984, and subsequently with co-workers), have added considerable weight to the passive erosional method of entry into the water column with subsequent transport and supposed recolonization of viable meiofaunal propagules. Swimming directly from the substratum into the water column (Hicks 1986. Walters \& Bell 1986, Bell et al. 1988), may be equated with over or through sediment recruitment as an active means of recolonization reliant ultimately, however, on the conveyance efficiency of near-bottom shear currents. The demonstration here of passive rafting is a third significant medium of recruitment which may assist in the rapid recovery of populations in disturbed habitat patches. It may be regarded as an airwater interface equivalent to Palmer \& Gust's (1985) mid-water flow related model of meiofaunal dispersal.

Sedimentary habitats represent mosaics of succes sional states including patches of free space generated by either biological or physical processes. Patches can be exploited by actively dispersing organisms or, less predictably in space and time, by those introduced passively. Both of these media are dynamic and have an impact on the successional state, the rate of population reassortment and the species that occupy space. Infaunal migration over or through sediments, active or passive water column entry with subsequent passive transport by water circulation, and passive sedimentfilm rafting must now be considered the primary means of providing recruits to exploit these patches. These 3 pathways involve species with differing dispersal capabilities and each pathway operates under the specific physical and climatic constraints at the site under investigation. These variabilities impose obvious difficulties on predictability, but nevertheless recognition of these agents of dispersal is important to the understanding of the dynamic nature of meiofaunal ecology and the factors that control such fundamental processes as recruitment and colonization.

Acknowledgements. To Susan Bell, Bruce Coull and Margaret Palmer go my sincere thanks for the time they spent reading the manuscript and for the suggestions made which have assisted its passage. Mark Strange kindly printed the photographs.

\section{LITERATURE CITED}

Alongi, D. M., Boesch, D. F., Diaz, R. J. (1983). Colonization of meiobenthos in oil-contaminated subtidal sands in the Lower Chesapeake Bay. Mar Biol. 72: 325-335

Ambrose, W G. Jr (1986). Experimental analysis of density dependent emigration of the amphipod Rhepoxynius abronius. Mar Behav. Physiol. 12: 209-216

Bell, S. S., Coen, L. D. (1982). Investigations on epibenthic meiofauna I. Abundances on and repopulation of the tubecaps of Diopatra cuprea (Polychaeta: Onuphidae) in a subtropical system. Mar. Biol. 67: 303-309

Bell, S. S., Sherman, K. M. (1980). A field investigation of meiofaunal dispersal: tidal resuspension and implications. Mar. Ecol. Prog. Ser. 3: 245-249

Bell, S. S., Hicks, G. R. F., Walters, K. (1988). Active swimming in meiobenthic copepods of seagrass beds: geographic compansons of abundances and reproductive characteristics. Mar Biol. 98: 351-358

Boaden, P. J. S., Platt, H. M. (1971). Daily migration patterns in an intertidal meiobenthic community. Thalassia jugosl. 7 . $1-12$

Carlton, J. T. (1985). Transoceanic and interoceanic dispersal of coastal marine organisms: the biology of ballast water. Oceanogr. mar. Biol. A. Rev. 23: 313-371 
Chandler, T G., Fleeger, J. W. (1983). Meiofaunal colonization of azoic estuarine sediment in Louisiana: mechanisms of dispersal. J. exp. mar. Biol. Ecol. 69: 175-188

Chislenko, L. L. (1974). Relationship between geographical distribution and abundance of marine harpacticids. Docklady Biol. Sci. 216: 218-220

Costerton, J. W., Geesey, G. G., Cheng, K.-J. (1978). How bacteria stick. Sci. A.m. 238: 86-95

Crosby, L. H., Ferguson Wood, E. J. (1959). Studies on Australian and New Zealand diatoms II. - Normally epontic and benthic genera. Trans. R. Soc. N. Z. 86: 1-58

Daniel, G. F., Chamberlain, A. H. L., Jones, E. B. G. (1987). Cytochemical and electron microscopical observations on the adhesive materials of marine fouling diatoms. Br. phycol. J. 22: 101-118

Edgar, G. J. (1987). Dispersal of faunal and floral propagules associated with drifting Macrocystis pyrifera plants. Mar. Biol. 95: 599-610

Fegley, S. R. (1987). Experimental variation of near-bottom current speeds and its effect on depth distribution of sandliving meiofauna. Mar. Biol. 95: 183-191

Findlay, S. E. G. (1981). Small-scale spatial distribution of meiofauna on a mud-and sandflat. Estuar. coast. Shelf Sci. 12: $471-484$

Fleeger, J. W., Chandler, G. T., Fitzhugh, G. R., Phillips, F. E (1984). Effects of tidal currents on meiofauna densities in vegetated salt marsh sediments. Mar. Ecol. Prog. Ser. 19: 49-53

Fletcher, M., Floodgate, G. D. (1973). An electron-microscopic demonstration of an acidic polysaccharide involved in the adhesion of a marine bacterium to solid surfaces. J. gen. Microbiol. 74: 325-334

Gerlach, S. A. (1977). Means of meiofauna dispersal. Mikrofauna Meeresboden 61: 89-103

Gislén, T (1940). The number of animal species in Sweden, with remarks on some rules of distribution, especially of microfauna. Lunds Univ. Arsskr N. F. Avd. 2, 36: 1-23

Grant, J., Bathmann, U. V., Mills, E. L. (1986). The interaction between benthic diatom films and sediment transport. Estuar. coast. Shelf Sci. 23: 225-238

Gunnill, F. C. (1982). Macroalgae as habitat patch islands for Scutillidium lamellipes (Copepoda: Harpacticoida) and Ampithoe tea (Amphipoda: Gammaridae). Mar. Biol. 69: 103-116

Harper, M. A. (1969). Movement and migration of diatoms on sand grains. Br. phycol. J. 4: 97-103

Harper, M. A., Harper, J. F. (1967). Measurements of diatom adhesion and their relationship with movement. Br phycol. Bull. 3: 195-207

Heip, C., Vincx, M., Vranken, G. (1985). The ecology of marine nematodes. Oceanogr mar Biol. A. Rev. 23 $399-489$

Hicks, G. R. F. (1977). Species composition and zoogeography of marine phytal harpacticoid copepods from Cook Strait, and their contribution to total phytal meiofauna. N. Z. Jl mar. Freshwat. Res. 11: 441-469

Hicks, G. R. F. (1984). Spatio-temporal dynamics of a meiobenthic copepod and the impact of predation-disturbance. J. exp. mar Biol. Ecol. 81: 47-72

Hicks, G. R. F. (1985). Biomass and production estimates for an estuarine meiobenthic copepod with an instantaneous assessment of exploitation by flatfish predators. N. Z. Jl Ecol. 8: 125-127

Hicks, G. R. F. (1986). Distribution and behaviour of meiofaunal copepods inside and outside seagrass beds. Mar. Ecol. Prog. Ser. 31: 159-170

Hicks, G. R. F., Coull, B. C. (1983). The ecology of marine meiobenthic harpacticoid copepods. Oceanogr mar Biol. A. Rev. 21. 67-175

Highsmith, R. C. (1985). Floating and algal rafting as potential dispersal mechanisms in brooding invertebrates. Mar. Ecol. Prog. Ser 25: 169-179

Hockin, D. C., Ollason, J. G. (1981). The colonization of artificially isolated volumes of intertidal estuarine sand by harpacticoid copepods. J. exp. mar. Biol. Ecol. 53: 9-29

Hulings, N. C., Gray, J. S. (1971). A manual for the study of meiofauna. Smithson. Contr Zool. 78: 1-83

Joint, I. R., Gee, J. M., Warwick, R. M. (1982). Determination of fine-scale vertical distribution of microbes and meiofauna in an intertidal sediment. Mar. Biol. 72: $157-164$

Kern, J. C., Bell, S. S. (1984). Short term temporal variation in population structure of two harpacticoid copepods, Zausodes arenicolus and Paradactylopodia brevicornis. Mar. Biol. 84: 53-63

Kingsford, M. J., Choat, J, H. (1985). The fauna associated with drift algae captured with a plankton-mesh purse seine net. Limnol. Oceanogr. 30:618-630

Lopez, G. W. (1982). Short-term population dynamics of Tisbe cucumariae (Copepoda: Harpacticoida). Mar. Biol. 68: 333-341

McCully, M. E., Goff, L. J., Adshead, P. C. (1980). Preparation of algae for light microscopy. In: Gantt, E (ed.) Handbook of phycological methods, development \& cytological methods. Cambridge University Press, Cambridge, p. 263-283

Montagna, P. A., Coull, B. C., Herring, T L., Dudley, B. W (1983). The relationship between abundances of meiofauna and their suspected microbial food (diatoms and bacteria). Estuar coast. Shelf Sci. 17 381-394

Palmer, J. D., Round, F. E. (1967). Persistent, vertical migration rhythms in benthic microflora. VI. The tidal and diurnal nature of the rhythm in the diatom Hantzchia virgata. Biol. Bull. mar. biol. Lab., Woods Hole 132: 44-55

Palmer, M. A. (1984). Invertebrate drift: behavioural experiments with intertidal meiobenthos. Mar. Behav. Physiol. 10: $235-253$

Palmer, M. A. (1986). Hydrodynamics and structure: interactive effects on meiofauna dispersal. J. exp. mar. Biol. Ecol. 104: 53-68

Palmer, M. A., Gust, G. (1985). Dispersal of meiofauna in a turbulent tidal creek. J. mar. Res. 43: 179-210

Palmer, M. A., Molloy, R. M. (1986). Water flow and the vertical distribution of meiofauna: a flume experiment. Estuaries 9: 225-228

Probert, P. K. (1984). Disturbance, sediment stability, and trophic structure of soft-bottom communities. J. mar. Res. 42: 893-921

Reidenauer, J. A., Thistle, D. (1981). Response of a soft-bottom harpacticoid community to stingray (Dasyatis sabina) disturbance. Mar. Biol. 65: 261-267

Sewell, R. B. S. (1956). The continental drift theory and the distribution of the Copepoda. Proc. Linn. Soc. London 166: 149-177

Sherman, K. M., Coull, B. C. (1980). The response of meiofauna to sediment disturbance. J. exp. mar. Biol. Ecol. 46: $59-71$

Sherman, K. M., Reidenauer, J. A., Thistle, D., Meeter, D. (1983). Role of a natural disturbance in an assemblage of marine free-living nematodes. Mar Ecol. Prog. Ser. 11. $23-30$

Sterrer, W. (1973). Plate tectonics as a mechanism for dispersal and speciation in interstitial sand fauna. Neth. J. Sea Res. 7: $200-222$ 
Taylor, W. R. (1964). Light and photosynthesis in interstitial benthic diatoms. Helgoländer wiss. Meeresunters. 10: 29-37

Thistle, D. (1980). The response of a harpacticoid copepod community to a small-scale natural disturbance. J. mar. Res. 38: 381-395

Van Blaricom, G. R. (1982). Experimental analyses of structural regulation in a maxine sand community exposed to oceanic swell. Ecol. Monogr. 52: 283-305

Walters, K. (1987). Experimental investigations of vertically migrating meiofaunal populations in subtropical sand and seagrass habitats. Ph. D. thesis, University of South Florida, Tampa
Walters, K, Bell, S. S. (1986). Diel patterns of active vertical migration in seagrass meiofauna. Mar. Ecol. Prog. Ser. 34 95-103

Wells, J. B. J. (1986). Biogeography of benthic harpacticoid copepods of the marine littoral and continental shelf Syllogeus 58: 126-135

Wiborg, K. F. (1964). Marine copepods of Tristan da Cunha. Results Norw. Sci. Exped. Tristan da Cunha 1937-38, 51 . $1-44$

Yeatman. H. C. (1962). The problem of dispersal of marine littoral copepods in the Atlantic Ocean, including some redescriptions of species. Crustaceana 4: 253-272

This article was presented by Dr R. M. Warwick; it was accepted for printing on June 24, 1988 